\title{
The voice of society in healthcare politics in Latvia
}

\author{
Ieva Bikava, Ilga Kreituse, and Andris Skride \\ Rīga Stradinsš University, Riga, Latvia
}

\begin{abstract}
It is impossible to imagine contemporary democracy without society participation in the process of developing regulations and implementation of changes that have a significant impact on society. The opinion of the society is represented by social communities, interest groups, and other non-governmental organizations, which unite people with similar views and ideas and serves as a representative of common opinion to government. The principles of good governance demand cooperation and collaboration with society in all phases of developing, implementing and assessing changes in any policy. The article represents the research on evaluation of cooperation and collaboration practice, as well as an assessment of used lobbying strategies and evaluation of their results in Healthcare politics in Latvia. The research is based on in-depth interviews with the representative of main actors presenting the NGO sector, as well as the representatives of the Ministry of Welfare. The research results indicated that actors that operate in Healthcare sector use all of the possible lobbying techniques with various outcomes. The achieved results are dependent on the skills and available resources of Interest groups, on the desire and possibilities to follow good governance principles in state authorities, as well as of the topical issue.
\end{abstract}

Key words: health policy, health governance, lobbying.

\section{Introduction}

Latvia is a state in transition or a "new democracy", located in the Baltic Sea region in Northern Europe. In 1990, Latvia regained its freedom, after being a part of the Soviet Union for fifty years. The healthcare system during the occupation period was totally centralized and all the decisions were made without public participation. The global changes in healthcare, started in the 1990s, were aimed to radically change the old structure that existed in the USSR - a completely centralized planned economy system, to a new, comprehensive, and decentralized system.

During the first decade of regained freedom, the changes in property rights occurred, by providing more possibilities for the private capital as well as changes in regulation to promote free market and competition elements in all sectors, including healthcare.

The vision to become democratic welfare state based in the models observed in developed countries: the model of private-public partnership, and the normative base was adjusted to comply with the requirements to become the part of the European Union. The decision to become a developed European country contributed to the changes in the way how the state was governed.

Since 2002 one of the goals, determined by the Government of Latvia, has been to promote the rise of civil society by providing the beneficial legislature and financial environment, as well as develop the State program on civil society development [1]. 
The State Administration Structure Law, adopted in 2002, determines the role of civic society participation in the State governance process describing the types of public participation, regulations for authorization and regulations for entering into participation contracts [2].

Since 2004 Latvia is a member state of the North Atlantic Treaty Organization (NATO) and the European Union. A desire to become a member of these organizations influenced the way how the state institutions communicate and collaborate with other parties - the institutions of other sectors, of other countries, as well as with the private sector and society.

In 2005, the developed "Guidelines for a policy to strengthen civic society" and the state provided programme "Strengthening civil society: 2005-2009" were approved by the Cabinet of Ministers. The main goals were the following: to increase the share of people in Latvia who, through formal and informal cooperation, act for their own and society's benefits and increase social capital; to improve the effectiveness of participation of citizens, informal groups and non-governmental organizations (NGO) in the political process at municipal, state, and the European Union level; to develop an environment for sustainable, resultoriented NGO activities [3, 4].

The state programme, as well as the activities funded by the other parties, provided necessary resources stimulated educational programmes and offered programmes to obtain the necessary skills for the NGOs that resulted in the significant rise of the NGO sector. The change in regulation and rising number and competency of NGOs, created the necessary conditions for involvement of society in state governing.

Although the normative regulation provides all the necessary tools to provide good governance, according to society opinion, the real possibilities to influence the processes are insufficient, especially in the healthcare sector. The state authorities, especially in Healthcare sector are separated from the society, and all the participation, that is required in the legislature, is provided only "on paper", but there is no place for dialogue and the authorities "hear, but not listen". At the same time, there are also examples of successful cooperation of the state and NGOs in different projects and successful programme implementation. That leads to the research issue - to find the factors that influence the abilities of society to get to the positive outcomes and influence the changes and reforms that are planned, developed and implemented, as well as to come to the state institutions with the new initiatives and successfully implement them.

The research question was - how well the voice of society is represented in the health sector, by providing possibilities to the healthcare actors represented by different NGOs to participate in the process of health policy development, implementation, as well as evaluation. To provide the answer, in-depth interviews were made with the representatives of the state part: The Minister of Health, the state secretary of the Ministry of Health, the official of the National Health Service, the representatives of the project departments of the Ministry of Health. From the NGO part - interviews were conducted with the representatives of Latvian Medical Association, Association of General Practitioners of Latvia, Association of Rural General Practitioners of Latvia, Association of Nurses, Trade Union of Medical Workers, Association of Major Hospital Employers, Trade union of Private Healthcare Employers, Association of Insurers, as well as Patient organizations.

\section{Contemporary governance and possibilities for NGOs in Latvia}

"Governance signifies a change in the meaning of government, referring to new processes of governing; or changed conditions of ordered rules; or new methods how society is governed". The governance also refers "to the changing boundaries between public, private, and voluntary sectors, and to the changing role of the state" [5]. 
The changing role of the state in the contemporary manner of state governing "marks a paradigm shift from the old regulation by command and control to a regulatory governance model, signifying a collective intellectual and programmatic project for a new legal regime" [6].

NGOs are formalized interest groups that are organized to defend the interests of their members of the values of the society by bringing the topical issue to the society, media and politicians and to work towards the desired outcomes.

To become a respected member that is welcomed by the state institutions to participate in political processes, the NGOs have to become recognizable and powerful, but to become influential it has to have lobbying skills. "The lobbying potential of any group is determined largely by the group's characteristics and resources. Crucial characteristics of a group include the unique collection of resources found among the membership, the structural aspects of the formal organization, and the quality of the leadership and the staff" [7].

There are two main strategies used to defend the interests of any interest group: direct and indirect lobbying. "Direct lobbying is the strategy preferred by the vast majority of interest groups. It is simpler, less dangerous, and less subject to misinterpretation than the more costly and complex strategy of indirect lobbying" [7].

Direct lobbying includes all the methods used in direct communication with the governmental decision making - writing letters, meeting in person, working in workgroups, attending the meetings of committees, submitting the opinion over the policy drafts, bringing the topical issue, providing the data, expertise, and information, working on research projects, etc. All those activities are included in terms of "cooperation" and "collaboration" among the state and non-state parties.

"Indirect lobbying is more circuitous as a communication process than direct lobbying. As it is more circuitous, there is an inherent risk of a message being garbled in the process and the additional problem of extraordinary costs involved in stimulating the grassroots or third parties into the lobbying game" [7].

Indirect lobbying includes all the methods that interest groups use to reach the desired outcomes, in most cases when the direct lobbying has not been effective or did not lead to the needed outcomes. Indirect strategies are aimed to activate the society and work towards the pressure to legislative bodies or politicians. Those methods are media campaigns, protests, demonstrations, boycotts, and initiation of referendums, disputing the legislation to court, as well as organizing lobbying coalitions with other players.

According to the normative regulation of Latvia, there are several ways, how the society can participate in the state governing process. The responsible institution for civic participation in the development and implementing process of any regulation is the State Chancellery, which is the central public administration institution, directly subordinated to the Prime Minister. In 2014, the Cabinet of Ministers approved the renewed memorandum signed between the NGOs and the Cabinet of Ministers with the aim to strengthen not only the discussion and public information, but also the decision-making process, its execution and control. One of the major improvements was the introduction of the "green paper" which means that before any regulation is reviewed in the government, it has to undergo the discussion process with society. The NGOs and other partners have to submit their opinion paper - to support the legislation project or object to it. As the Cabinet of Ministers suggests most of the changes in legislation, the majority of the normative regulation undergoes this public discussion phase.

There are several additional ways and points by which the society can affect the normative legislation. In the process of developing government goals and guidelines, or evaluating existing policies, NGOs can raise the importance of the issue by attracting the attention of politicians and the media. They can cooperate with the Prime Minister 
candidate and political parties (at the time of drafting the Declaration of the Government), with ministers and ministries of the new Cabinet of Ministers during the preparation and implementation of the Government Declaration Action Plan and keep track of declared tasks, plans and activities. In the process of drafting the policy planning documents and legislation drafts - according to the theory, this is the point, where active participation of the NGOs can be the most beneficial and lead to the best desired outcomes. During this phase, NGOs can participate in the working groups of a policy planning documents or legislative act, giving an opinion at the meeting of the State Secretaries, or a meeting of the Cabinet Committee, or at the meeting of Cabinet of Ministers [8].

In the process of decision-making, NGOs can be as partners for the ministry responsible for the legislature project in one of the following roles: 1) Additional source of expertise and information; 2) A partner in policy formulation, explanation, and implementation or evaluation; 3) Be on the alert for potential risks or failures of the policy; 4) Be the promoter of the public administration by encouraging professionalism when formulating policies in a more comprehensible manner to the public, as well as consulting the society in a timely manner. Executing one or several of the mentioned roles NGOs, during the decision-making stage, can submit proposals and opinions on draft legislation at any stage of the document. Later they can participate in the meetings and explain their concerns or position, as well as encourage discussion of the regulation draft at a Memorandum Council meeting, as well as express their opinion on those laws and regulations that have been forwarded for approval to the Memorandum Council [8].

If the draft of regulation is the change in the law, then NGOs can also participate and be involved in the draft reviews in Parliament Committees. When the draft is forwarded to the responsible Committee for further consideration, NGOs can submit their proposals and work towards attempting meeting the deputies or Committee personally to explain their views. When the law has passed all three (or two) hearings in the Parliament and has been approved, there is still possibility to impact the law to come into force, by addressing the President to hear the views of NGOs in order to influence the promulgation of a legislative act draft, to propose its revision, to supplement or to amend it [8].

In the last phase, policy implementation and evaluation process, there are also several ways how NGOs can make an impact to it. One of them is - to actively follow up and participate in the evaluation of policy programs by participating in working groups. They can explore specific issues within the projects, or express their views on the problem by addressing letters and statements to officials of the responsible authorities, as well as by updating the debate on the issue through the media [8].

The possibilities for NGOs to participate in the whole process of the government in Latvia, according to the described above are completely compliant with the comprehension of the participatory or collaborative governance. Which is "a strategy used in planning, regulation, policy-making, and public management to coordinate, adjudicate, and integrate the goals and interests of multiple stakeholders" or in the narrower sense "a technique used to resolve conflict and facilitate cooperation among public agencies, interest groups, and citizens". Or in the more ambitious sense "collaborative governance refers to a strategy for reconstructing democracy along less adversarial and managerial lines" and "seeks to restore trust in government and expand democratic consent by deepening participation and deliberation in public affairs" [9].

From all the above mentioned, the possibilities of civic participation are provided in Latvia, and "on paper" the civic participation is welcomed. The only limits are in the form of participation - there is no space for single individual participation, but only for the organized group. Of course, individuals can be invited to participate in working groups as experts, but to act as a society the individuals have to form the organization and register the NGO in 
Enterprise Register of Latvia. Although the only direct lobbying methods are listed above as the ways to affect the government in cooperation and collaboration, the legislature of Latvia also allows using all the indirect lobbying methods.

As to the healthcare, the most appropriate is the World Health Organization (WHO) definition "Governance in the health sector refers to a wide range of steering and rulemaking related functions carried out by governments/decisions makers as they seek to achieve national health policy objectives that are conducive to universal health coverage. Governance is a political process that involves balancing competing influences and demands" [10].

As stated in WHO definition, the good governance means that all stakeholders are acting together to achieve common goals. The changing role of the state model from the past vertical power to contemporary horizontal model changes also the duties of the state authorities. The main tasks have become to maintain the strategic direction of policy development, detecting and correcting activities, information and bargaining activities as well as balancing interests and power towards achieving the best outcomes for the whole society that sometimes means, ignoring or limiting some interest group demands in favour of the society's benefits.

There are several examples of different lobbying methods and strategies that used by the NGOs in the healthcare sector in Latvia, with different outcomes and different lessons to learn. That will be in details analyzed in the next section.

\section{The assessment of lobbying tools used by NGOs}

The research on lobbying strategies and the used methods in the Healthcare sector showed that all kinds of methods have been used, mostly direct lobbying methods, but also indirect lobbying methods.

The most common methods, used by all the NGOs that are acting in healthcare sectors - associations of doctors and medical nurses, patient organizations, trade unions, and others - were the cooperation and collaboration at the very beginning of every change in Healthcare system. They work hand-to-hand with the ministry of Health or the institutions that are subordinated to the Ministry of Health, like National Health Service. The representatives of those NGOs on regular basis meet the representatives of the state institutions to discuss the topical issues. In most cases, there are two results: if the discussion is successful, and the state institution approves the issue, then the work on the topic starts. If the issue is not interesting to the institution (those are mostly the cases when extra funding is needed or no clear benefits or outcomes are provided by the NGOs, or the changes do not comply with the institutional goals), then no next steps are taken and the work on the issue is postponed.

Interviews with the representative of the chair of the Medical Nurse Association (MNA), describing the cooperation and collaboration with the Ministry of Health characterizes the work with state authorities as very productive, despite the dramatic situation in nurse availability in Latvia. MNA together with the Ministry of Health are working on several issues to improve the prestige of the nurse profession as well as on changes in education and certification system, and different motivating and stimulating programmes. Despite the low salary problems that have led to the crisis in the healthcare sector, the relationships between the MNA and Ministry are very productive.

As the representatives of the Ministry described the cooperation process, the Ministry completely understands the salary problem, but as the politicians are not granting more funding to the healthcare, there are no possibilities for the Ministry to solve this problem, so they are supportive to activities of Medical Nurses to raise the concerns in society. In this case, indirect lobbying activities do not have a negative impact on the cooperation, as both 
parties are working on the topics that can be solved and improved using the tools and abilities the Ministry have.

As the representatives of the Ministry described - the MNA comes to the Ministry with realistic and practicable proposals. For example, to delegate more duties to the nurse profession, using the experience of other countries, as well as to change the duties of the nurse in order to increase the salary, since part of the tasks, now carried out by the medical doctor, can be done by nurses. Another proposal is - based on other countries' experience and taking into account the situation with the dramatic shortage of nurses, make changes in legislature, to provide an easier way to become a certificated nurse, as well as to prepare changes in the educations system to provide comprehensive knowledge and skills, without such fragmented specialization. The collaboration of MNA and the Ministry of Health showed an excellent example of the good participatory governance in the case, when the NGO has the knowledge and expertise and is open to discussion, and can provide state institutions with initiatives that have a well-prepared background and can solve actual problems.

Another example of good cooperation between the Ministry of Health and NGO was the Association of Rural General Practitioners (ARGP). The situation with the General Practitioners (GP) in rural areas is also problematic, and there are several topics, in which the opinion of the ARGP and the Ministry of Health are radically opposite. Dissatisfaction with the situation was even so dramatic, that in the summer of 2017, GPs went on a strike. However, despite those events, the ARGP describes the cooperation with the Ministry on a positive note. Both parties understand that the changes and new political initiatives can be passed only according to the available state funding and open projects of other funds, and unfortunately, several good initiatives have been postponed because of the lack of funding. But at the same time, there are several good ideas that parties work on and that have been already implemented, for example, the change in regulation providing the priority to get statepaid residency studies for the medical students, who have contracts to work in rural areas. Or - the additional higher salary if the specialists work in the regional clinics initiative provided by the program funded by European Regional Development Funds.

On the contrary, another association of GPs characterizes cooperation with the Ministry in a very negative tone. In their opinion, there is no cooperation or collaboration, and the state institutions do not want to solve any of the GPs' problems. The NGO points out that the Ministry do not take into account their opinion and the answers to the letters, sent to the state authorities, are just formal as are all the other activities that carried out by the state. The NGO, referencing to the bad previous experience is not interested to come to the meetings and provide their proposals, because they do not see it as their duty to provide information, data and proposals. In their turn, the representatives of the Ministry pointed out that cooperation with this NGO is hard because they are not interested in the collaboration and working in hand-to-hand, but only wait for the problems to be solved. If the ministry cannot guarantee the desired result, they are not open for discussion but run straight to the media and just criticize the state institutions.

A similar situation as with two GPs associations is with two other NGOs - the representatives of the major rural hospitals of Latvia and the representatives of the three clinical university hospitals. Despite the fact that the situation with medical staff availability, funding, and other problems is much harder in the three clinical hospitals, the cooperation is almost impossible with the major clinical hospital representatives. Comparing results of that experience, one of the factors, revealed during the research, was the leadership of the NGO and their attitude and knowledge of the role and duties of NGOs.

Cooperation was successful in cases when the chairs or the main leaders of the NGO were from the "new generation", the generation that is of younger age and has experience 
in working abroad, or have obtained special leadership and management skills, the leaders who are goal and solution-oriented. By contrast, the leaders from the previous generations (approaching retirement age), see their position as being critical and do not want to participate in the process of searching the solution. They prefer waiting for the Ministry to solve the problem, seeing it as the responsibility of the Ministry: the duty of doctors is to treat patients, not to do the Ministry's work providing political solutions. The same was observed in the process of changing the chair in Latvian Medical Association. The former chair was famous with the articles and interviews criticizing every Minister of Health, but was not interested in any cooperation and collaboration, and considered that the main duty of the NGO was to support only the education and certification of medical specialists. After the change of chairs, the Medical Association became more open to cooperation and collaboration activities, provided more ideas and proposals on the legislature change and initiation of working groups.

Health Care Employers Association, which is a part of Latvian Employers Confederation, represents the interests of private healthcare institutions, mostly of primary care and some private clinics. NGO actively participates in cooperation and collaboration activities in all levels of decision-making and is a welcomed partner of the state institutions. Of course, there are some conflicting points between state owned institution and private capital institution interests, but all parties see it as normal part of the collaborative work, and the state perform the regulative actions to find the balance in the arena of conflicting interests. It is important to mention that, in the case of this NGO, the active participation in policy development and implementation process was one of the strategic goals. The NGO hired the leader with great lobbying skills - the former head of the State Revenue Office with more than 20-yearexperience in the leading positions in state administration.

Trade Union of Health and Social Care Employees of Latvia is very sceptic about the work of the Ministry of Health and its subordinated institutions. At the same time, the NGO is the respectable partner, who is invited to participate in workgroups and meetings in all stages of the legislature development and approval. NGO is also the member of national tri-parity council. Although the NGO is active, the results of their work are ambiguously evaluated. For example, the infringement of the legislature known as "extended work hours" was accepted during the economical crisis in 2008. It determined that medical staff can work more than 40 hours a week -60 hours a week without having the extra pay for overtime. For the other fields, in case the employee is working more than 40 hours a week, the overtime is paid in double amount. However, it was not the employees' trade union but doctors themselves, who initiated the change in legislature by addressing the Ombudsman. Moreover, in other issues that are significant to employees the trade union do not work actively. Most of activities of the trade union are indirect lobbying forms. For example, organizing the protests (in 2016), participating in media lobbying campaigns, and being a partner in lobbying coalitions by expressing support to activities performed by other NGO, such as expressing support to General Practitioners' strike in 2017, or participating in the protest activities performed by the Latvian Medical Association and Association of Young doctors at the end of 2019.

According to patient organizations, the opinion about possibilities to affect the policy is very different. Some NGOs are very positive, but some are very negative. The research also showed that one of the factors is age, as well as education and previous experience of the leading persons of NGO. There are patient organizations, which see their role only as to inform the officials, politicians and media about their problems and difficulties. At the same time, there are NGOs that see their roles as active participants and managers of changes. They actively participate in workgroups and collaborate with all kinds and levels of partners officials, politicians, other NGOs on national and international level. They also participate in 
obtaining funding for different initiatives in the state provided programs, and by the European Union and internationally provided funds from other countries.

There were two researches previously made, where the involvement of the society was analyzed. One: The E-health (National Electronic Health Record System) implementation in Latvia, that took place in the period from the $2008-2018$, and the other: development of the HIV/AIDS policy in Latvia that applies to time-period 2015 - 2019. Comparison of those two research results revealed that situation over the years has changed significantly.

The analysis of the E-health implementation leads to results that one of the factors leading to the fail of implementation was that society and NGOs were not involved in the development phases at the starting point in 2008, which led to protests and even boycotts from the stakeholders and the responsible authority did not have needed governance skills $[11,12]$.

Contradictory, the research on HIV/AIDS policy and initiative development and implementation during the period of 2015-2019 indicated that cooperation and collaboration were very successful [13].

Those results lead to the conclusion that in the course of time and due to changes in legislature that entered into force in 2014 positive effect on cooperation and collaboration practice occurred, and the possibilities of organized society to affect the changes have become more powerful.

\section{Research results}

According to research results, NGOs acting in healthcare field are active partners that cooperate and collaborate with government institutions. Some of the NGOs have the attitude that their position is threatened and that the identified potential risks mostly are not taken into account and serve only as the fact, sometimes the discussions are only formal but not oriented to the problem solving. Others are more positive about cooperation and collaboration with state institutions and had successful experience with good outcomes

The outcomes of the cooperation and collaboration depend on several factors. One of the most influential factors is the attitude of parties - whether their attitude is positive and they come to the meeting with the common goal to work together and find the best possible solution, considering all aspects and limitations, or they come with the attitude that the meeting is formal and nobody is interested in finding the desired solution. In this case, there is no place for any compromises.

The second important factor is the competency and expertise of the NGO. As pointed by state institutions, best examples of successful projects were cases when the NGOs came to institution with the data, information and some ideas of possible problem-solving possibilities. On contrary, the worst experience of collaboration was when the NGO came to state institution taking the position - we have the problem, you are responsible for that, so find the solution and provide it already tomorrow! The same bad experience occurs in cases when NGOs come to the responsible authority with the project ideas and ask for funding without providing benefits and outcomes that could be achieved by this funding. Moreover, they do not show how these achievements are related to the healthcare policy goals or the goals of the special program under which the funding could be attained.

The results of this research are in accordance with the lobbying theory - the best results are achieved using the direct lobbying methods, especially when the lobbying activities start at the very beginning of the regulative change - working hand in hand with the representatives of the Ministry of Health or its subordinate institutions. However, taking into account the long path from the initiation to implementation, the NGO has to be active in the whole process, 
because in every point of the chain, where the regulation or law is reviewed, some changes can occur and NGO has to defend their position through entire path.

Indirect lobbying activities differ in their results, especially the media lobbying. In cases when the regulation is recognized as necessary from all the parties - NGO and responsible authorities, but there is insufficient support from politicians or society, then those lobbying campaigns in order to promote the change implementation are beneficial for all parties and help build better relationships for promotion of other changes in future. When the media campaigns are against the regulation or law implementation, in some cases they lead to desirable outcomes - postpone implementation or raise the public discussions, or force to more explanation or rework from authorities, but they also have the negative impact on relationships in further cooperation.

Other indirect lobbying activities - as the protests, strikes and demonstrations, as well as initiatives for referendums also had some impact on the government or the responsible institutions, but in all cases, related to healthcare in Latvia - they did not lead to desired results. Of course, they forced responsible authorities to give more interviews and more explanation to society, but the requested results were not achieved.

The voice of society can be a strong instrument that leads to necessary changes, if experienced NGOs use it in the right direction by a skilled leader. By contrast, in the hands of a weak and ignorant user, it can be as a "scream in the desert" or just wasting of time and resources without any benefit or even worsening of the situation. The lesson that can be learned from this research is - the best way to solve the problem is to identify the reason, find responsible authority, meet and talk in person, then - work as good partners in order to find the best possible solution and keep on track until the change is implemented - or, in short, use direct lobbying methods. Only in case, when the other side is "blind and deaf" and there is nothing more that can be done in constructive way - turn to media, raise the anxiety in society - by performing protests, boycotts and referendum initiatives.

\section{Conclusions}

Summarizing the research results - Latvia is a democratic state that is governed according to contemporary governance principles, providing the participatory and collaborative governance and appropriate normative base to provide civic participation in every phase of the regulations, from problem defining and change initiation, through decision making and implementation, and till the implementation and evaluation phase. However, the evaluation of possibilities to affect the changes differs, and depends on the NGO and the issue.

The weaker NGOs that only can talk about the problem, and are more oriented to communicate to media but not to participate in hard and long-term work in cooperation, or do not have appropriate knowledge, data and expertise, are not welcomed in collaboration activities and are more sceptical about the possibilities to have an impact on the processes. The more advanced NGOs that have become the partners of the state institutions, are responsive to participate and provide necessary knowledge, data, and expertise and have some proposals of possible solutions, are more welcomed to state institutions and are more optimistic about the possibilities to impact the processes in the field.

The outcomes of cooperation and collaboration, of course, depend on both parties as NGOs, as state institutions. The research results showed that in the course of time the institutions have become more open and more oriented to society involvement. Moreover, if in the case of E-health development in 2008 the involvement of stakeholders was insufficient, today - the interest groups are good partners of government and starting from 2014, this is not only a good will but also the necessity to pass the legislature to the Cabinet of Ministers. 


\section{References}

[1] Cabinet of Ministers, Deklarācija par Induïa Emša vadīta Ministru kabineta iecerēto darbību (Declaration of Cabinet of Ministers). Available: https://mk.gov . lv/sites/default/files/editor/emsis-deklaracija.pdf

[2] Parliament of Latvia, State Administration Structure Law. Available: https:// likumi.lv/ta/en/en/id/63545-state-administration-structure-law

[3] Cabinet of Ministers, Par Pilsoniskās sabiedrības stiprināšanas politikas pamatnostādnēm 2005-2014 (Guidelines for a policy to strengthen civil society). Available: https://m.likumi.lv/doc.php?id=101882

[4] Cabinet of Ministers. Par valsts programmu "Pilsoniskās sabiedrības stiprināšana. 2005-2009. gads (State provided programme "Strengthening civil society: 20052009”). Available: https://likumi.1v/doc .php?id=103070

[5] R. A. W. Rhodes, Waves of Governance, In: Oxford Handbook of Governance, 33-48 (Oxford University Press, 2012)

[6] O. Lobel, New Governance as Regulatory Governance. In: Oxford Handbook of Governance, 65-81 (Oxford University Press, 2012)

[7] R.J. Hrebenar, Interest Group Politics in America (Rutledge London and New York, 2015)

[8] Valsts Kanceleja. Sabiedrības līdzdalības iespējas. (The State Chancellery. Opportunities for public participation). Available: https://www.mk.gov.lv/lv/ content/lidzdalibas-iespejas

[9] C. Ansell, Collaborative Governance. In: Oxford Handbook of Governance, $498-$ 511 (Oxford University Press, 2012)

[10] World Health Organization. Health Systems. Governance. Available: https://www . who.int/healthsystems/topics/stewardship/en/

[11] I. Bikava, I. Kreituse, Interest Group Impact on E-health implementation in Latvia. Available:

https://www.shs-conferences.org/articles/shsconf/abs/2018/

01/shsconf_shw201802001/shsconf_shw2018_02001.html

[12] I. Bikava, I. Kreituse, Governance - the Key Factor of E-health Implementation in Latvia. Available: https://www.sgemsocial.org/index.php/elibrary?view= publication\&task=show\&id $=1450$

[13] I. Bikava, I. Kreituse, Cooperation and Collaboration Impact on Policy Development: HIV/AIDS Policy in Latvia. Available: https://www.davidpublisher.org/ index . php/Home/Article/index?id=41495.html 